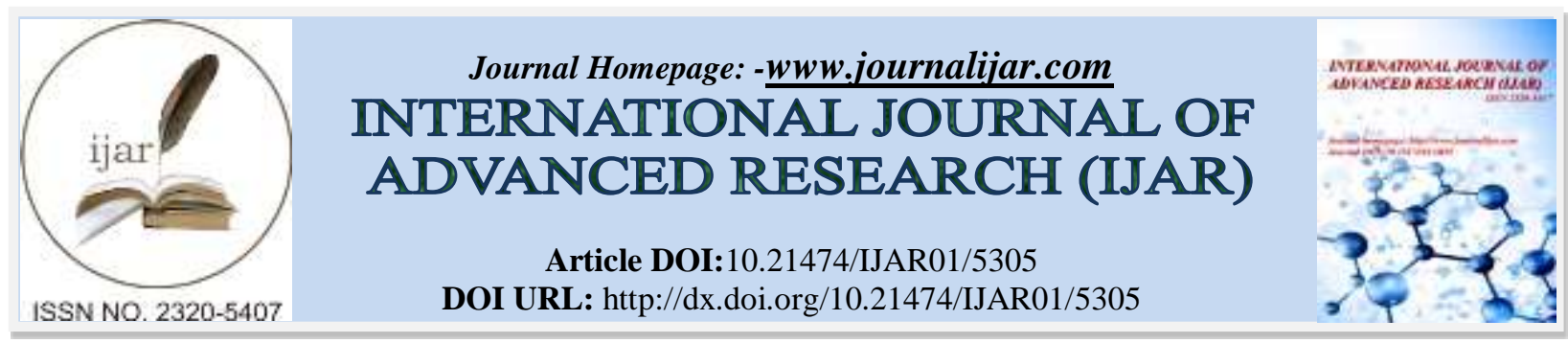

RESEARCH ARTICLE

\title{
STUDY OF EFFECTIVENESS OF CONCEPT ATTAINMENT MODEL OF TEACHING ON ACHIEVEMENT IN SCIENCE AMONGSECONDARY SCHOOL STUDENTS.
}

\author{
Dr. Md. Mahmood Alam. \\ Assistant Professor, MANUU College of Teacher Education, Sambhal -244302 (U.P.), A Constituent College of \\ Maulana Azad National Urdu University, Hyderabad.
}

\section{Manuscript Info}

Manuscript History

Received: 02 July 2017

Final Accepted: 04 August 2017

Published: September 2017

Key words:-

Concept Attainment model,

Conventional Teaching Method,

Achievement.

\section{Abstract}

The present study was conducted to investigate the effect of concept attainment model of teaching on achievement in teaching of science among secondary school students. The data was collected using Group Test of General Mental Ability constructed by S.S. Jalota (1972) and Achievement test in Sciences prepared by Investigator. Data included 120 randomly selected students of IX th class from two schools (1 Government and 1 Private) at Aligarh (U.P.). Descriptive and inferential statistics were used to compare the means between the groups. Finding of the study revealed that concept attainment model is effective in terms of achievement of students in teaching of science.

Copy Right, IJAR, 2017,. All rights reserved.

\section{Introduction:-}

Education is a process which revolves around teacher, student and curriculum where teacher has to play a very important role. The process of teaching and learning succeeds when it is properly planned and meticulously executed. The content and techniques of teaching depends to a great extent on what we want to achieve. With the changing scenario of education it is supposed to find ways and means to improve the teaching techniques to cope with the need of the times. What helps to make this possible is the process of concept attainment and development. Concept attainment is the process of defining concepts by determining the attributes that are absolutely essential to the meaning making and discriminate between what is and what is not an example of the concept. A teacher has to master multiple roles in order to become more professional. The professional competence can be expanded in two ways: first by increasing the range of teaching strategies that are needed to be employed; second by becoming increasingly skilful in the case of these strategies (Joyce and Weil, 1972). Bruner also emphasized four major features of theory of instruction in effective teaching. 1. Predisposition towards learning 2. Structural body of knowledge 3.Sequences of material to be learnt and 4.Nature and pairing of reward and punishment.

A theory of teaching must attempt to set forth the means of maximizing learning, needed learner behavior, intellectual development and acquisition of knowledge and specific mental process like reasoning, logical thinking, deductive reasoning and scientific creativity be primary concerns for effective and efficient information processing. In the recent past many methods of learning have been designed and applied to see its impact in different learning situation. But its appropriateness can only be judged through research keeping each Model's instructional and nurturing effects in view. Teaching of science is based on abstract ideas and concept. It is therefore important that new methods and techniques of teaching must be introduced in order to make the teaching of science more effective and efficient. Hence the learners must be prepared to process information suitably and meaningfully so that the information can be retained for a longer time and can be used in different situations of life. Because of the 
importance of concept attainment model of teachingfor youngsters' achievement in academics, it is apparently relevant to study effectiveness of concept attainment model of teaching on achievement in science among secondary school students.

\section{Conceptual framework:-}

Concept Attainment Model: Concept and definitions:-

Concept attainment is the process of defining concepts by determining the attributes that are absolutely essential to the meaning and discriminate between what is and what is not an example of the concept. The concept attainment model is historically linked with the work of Jerome $\mathrm{S}$. Bruner and his associates. The concept attainment model is designed to teach concepts and help students become more efficient at learning and creating concepts. It is effective in defining, comprehending, applying, and using concepts. The Concept Attainment Model is based on the research efforts of Jerome Bruner. This model is designed to lead students to a concept by asking them to compare and contrast examples that contain the characteristics or attributes of the concepts with examples that do not contain these attributes. It is based on the assumption that one of the best ways to learn a concept is by observing examples of it. Cele (1988) described that concept attainment model is a teaching strategy based on analysis of the nature of concepts and how they are acquired. Concept attainment model is a search for "listing of attributes that can be used to distinguish exemplars from non-exemplars" of various categories (Joyce \& Weil 2007).

\section{Review of the related literatures:-}

Verma (2001) reported that concept attainment model improves the inductive reasoning ability of the students. Sreelekha and Nayar (2004) conducted a study to compare the achievement level between traditional method and concept attainment model with respect to knowledge objectives, understanding objectives and application objectives. They found that concept attainment model is effective in improving the overall level of achievement in chemistry. Shamnad (2005) in his study found that the concept attainment model is more effective than conventional method in teaching Arabic grammar in IX th class. Kalani (2008) in a study found that achievement of students who were taught by concept attainment model was better than those who taught by the control method. Yaghini (2008) in her study concluded that there is relationship between preschool children learning who trained numerical mathematics concepts by concept attainment and children in traditional group. Vyas (2014) reported that effect of concept attainment model of instruction was significantly higher on the over, normal and under achiever students. Researches conducted on concept attainment model depict that student achievement improves when taught through this model. However, studies determining the effectiveness of concept attainment model on achievement of students in science teaching at secondary school level is nil or negligibly small. Therefore this scanty research inspired the investigator to undertake the present study to ascertain the effectiveness of concept attainment model of teaching on academic achievement in sciences.

\section{Objectives:-}

In the light of the review of the literatures, the present investigation was conducted with the following objectives:

1. To investigate the difference in achievement in the mean pre- test scores of control and experimental groups of secondary school students in science teaching.

2. To investigate the difference in achievement in the mean post- test scores of control and experimental groups of secondary school students in science teaching.

3. To investigate the difference in achievement in the mean post- test scores of secondary school boys and girls of experimental group in science teaching.

\section{Hypotheses:-}

Based on the review of literature and aforementioned objectives the present study formulated the following hypotheses:

1. There is no significant difference in achievement in the mean pre-test scores of control and experimental groups of secondary school students in science teaching.

2. There is no significant difference in achievement in the mean post- test scores of control and experimental groups of secondary school students in science teaching.

3. There is no significant difference in achievement in the mean post-test scores of secondary school boys and girls of experimental group in science teaching.

Delimitations of the study: The study is delimited to 
1. The secondary school students studying in IX th class only.

2. Sample size of 120 only.

3. Achievement is compared to those who fall in the average intelligence group.

4. Town area schools only.

5. The tools:

- Group Test of General Mental Ability (GTMA) developed by Dr. S. S. Jalota (1972) was used for selection of groups.

- Achievement test in science prepared by investigator

\section{Methodology:-}

This study utilized experimental techniques due to its nature. This section is comprised of sample, research tool and procedure of the data collection.

\section{Sample:-}

The present study was conducted on a sample of 120 IX th class students selected using purposive sampling technique from government and private schools of Aligarh (U.P.). The ages of the students ranged from 14 to 15 years.

\section{Tools used:-}

The researcher used the following tools for collecting the data to study the research in hand.

\section{Group Test of General Mental Ability (GTMA) 1972 by Jalota}

Group Test of General Mental Abilityhas been constructed and standardized by Dr. S. S. Jalota (1972).This intelligence test comprises of five separate categories of twenty tasks each, namely: (i) Vocabulary (ii) Classification (iii) Number Series (iv) Analysis and (v) Reasoning. This test was employed by the researchers for the purpose of data collection. The reliability of the test was found to be +.938 and the validity of the test ranged from +.50 to +.78 .

\section{Achievement test in sciences prepared by investigator.}

\section{Procedure of data collection:-}

Pre-test and post-test experimental design was used in the study. All the selected students of class IX th were given the objective type achievement test prepared by the investigator with the help of the experts on the selected science topics. Their achievement/test scores were recorded. Intelligence test, developed by Dr. S.S. Jalota was also simultaneously administered to them for selection of the groups. Students were selected on the basis of their intelligence score. The students were then divided into two groups i.e. experimental group and control group. The experimental group was taught through concept attainment model of teaching and the control group was taught through traditional method. Both the groups were again tested with the same test that was administered in the beginning before starting the experimentation. The scores obtained by both the groups in the post-test were also recorded. These scores of pre-test and post-test were utilized in the analysis of the data.

\section{Analysis of the data:-}

Descriptive statistics (Mean, Standard Deviations) were used to compare groups on pre-test scores \& post-test scores and inferential statistics ' $t$ ' test was applied to compare the mean post- test scores of experimental and control groups to ascertain the effect of concept attainment model on academic achievement in sciences.

\section{Results and discussion:-}

The comparison of the samples was done by testing the significance of difference between mean pre-test scores of experimental and control groups using t- tests. The results are presented in the following tables:

Hypothesis 1: There is no significant difference in achievement in the mean pre-test scores of control and experimental groups of secondary school students in science teaching.

Table 1:- Showing 't' value of mean pre-test scores of control and experimental groups of secondary school students in science teaching

\begin{tabular}{|l|l|l|l|l|l|}
\hline Groups & N & Mean & S.Ds & t- value & Level of Significance \\
\hline Control & 60 & 15.14 & 2.54 & 0.410 & Non-significant \\
\cline { 1 - 2 } & 60 & 14.96 & 2.27 & & \\
\hline
\end{tabular}


Perusal of the table- 1 reveals that the mean pre-test scores of control and experimental groups are 15.14 and 14.96 and their S.Ds are 2.54 and 2.27 respectively. When the t-test was applied to compare the mean pre- test scores of both the groups, $\mathrm{t}$-value is found to be 0.410 which is non-significant. This shows that there exists no significant difference between the mean pre-test scores of control and experimental groups. Hence the null hypothesis 1 is accepted.

Hypothesis 2: There is no significant difference in achievement in the mean post- test scores of control and experimental groups of secondary school students in science teaching.

Table 2:- Showing 't' value of mean post- test scores of control and experimental groups of secondary school students in science teaching

\begin{tabular}{|l|l|l|l|l|l|}
\hline Groups & $\mathrm{N}$ & Mean & S.Ds & t-value & Level of Significance \\
\cline { 1 - 4 } Control & 60 & 20.59 & 2.05 & 9.12 & .01 \\
\cline { 1 - 4 } Experimental & 60 & 24.12 & 2.20 & & \\
\hline
\end{tabular}

Table- 2 reveals that the mean post -test scores of control and experimental groups are 20.59 and 24.12 and their respective S.Ds are 2.05 and 2.20. When the t-test was applied to compare the mean post- test scores of both the groups, $\mathrm{t}$-value is found to be 9.12 which is significant at .01 level of significance favoring the later. This suggests that experimental group has higher mean post- test scores as compared to control group. It can, thus, be inferred that experimental group is more encouraged and enthusiastic in learning, applying and correlating the concepts simultaneously resulting into their better achievement. This result is in consonance with the researches of Sreelekha and Nayar (2004) and Yaghini (2008). Hence the null hypothesis 2 is rejected and it may be reframed as there is significant difference in achievement in the mean post- test scores of control and experimental groups of secondary school students in science teaching.

Hypothesis 3: There is no significant difference in achievement in the mean post-test scores of secondary school boys and girls of experimental group in science teaching.

Table 3:- Showing ' $t$ ' value of mean post- test scores of boys and girls of experimental groups of secondary school students in science teaching

\begin{tabular}{|l|l|l|l|l|l|}
\hline Groups & $\mathrm{N}$ & Mean & S.Ds & t-value & Level of Significance \\
\hline Boys & 30 & 24.83 & 1.98 & \multirow{2}{*}{1.290} & \multirow{2}{*}{ Non-significant } \\
\hline Girls & 30 & 24.20 & 1.81 & & \\
\hline
\end{tabular}

Perusal of the table- 3 reveals that the mean post-test scores of boys and girls are 24.83 and 24.20 and their S.Ds are 1.98 and 1.81 respectively. When the t-test was applied to compare the mean post- test scores of both the groups, tvalue is found to be 1.290 which is non-significant. This insignificant result might be due to their similar developmental ability in comprehending, applying, and using concepts in learning situations resulting in the equal levels of achievements. Hence the null hypothesis 3 is accepted.

\section{Findings:-}

1. No significant difference is found in achievement in the mean pre-test scores of control and experimental groups of secondary school students in science teaching.

2. Significant difference is found in achievement in the mean post -test scores of control and experimental groups of secondary school students in science teaching.

3. No significant difference is found in achievement in the mean post-test scores of secondary school boys and girls of experimental group in science teaching.

\section{Conclusion:-}

Concept attainment model was found to be effective in influencing the achievement in sciences among secondary school students as it is evident from the post- test scores of control and experimental groups. The findings of this study have meaningful implications for parents, teachers, educational planners and learners. They need to know the causes affecting students' achievement level and build on their strength to sustain their motivation. A cooperative and participatory educational system providing space to the students should be put in place where they will have an ample of opportunities to test their abilities and quenches their intellectual thirst. Therefore, all learners should be 
given equal opportunity and the same level of encouragement irrespective of their locale, gender and types of school to engender higher level of performance in secondary school. All stakeholders in education should ensure that students are highly motivated by providing necessary materials, enabling environment and adequate reward system.

\section{Educational Implications:-}

The present study reveals that concept attainment model was effective in terms of understanding of concepts of sciences. It plays a significant role in improving the achievement of students. Hence, CAM should be used by the school teacher in class-room teaching in general and teaching of science concepts in particular. CAM helps in strengthening the cognitive structure of the students. In order to orient the interest of teachers towards the use of CAM in classroom teaching, workshops and seminars should be organized.

\section{References:-}

1. Anjum, S. K. (2014), "A Study of Effect of C.A.M on Achievement of Geometric Concepts of Viii Standard Students of English Medium Students of Aurangabad City", Scholarly Research Journal for Interdisciplinary Studies, 2(15), 2451-2456.

2. Best, J.W. and Khan J.V. (1995), "Research in Education(7th edition)", Prentice Hall of India Pvt. Ltd., New Delhi.

3. Das, S. K. (2013), "Effectiveness of C.A.M and Advance Organizer Model in Mathematics Achievement among Ninth Grade Students in Roopnagar District of Punjab". http://ssrn.com/abstract=2329883

4. Garret, H.E. (1981), "Statistic in Psychology an Education", Feffer and Simons Ltd, Bombay.

5. Good, Carter V. (1966), "Essentials of Educational Research: Methodology and Design", Meredith Publishing Company, New York.

6. Jalota, S.S. (1972), "Manual of Group Test of General Mental Ability", 225, Sector 16-A Chandigarh.

7. Joyce, Bruce and Weil, Marsha (1997), "Models of teaching", New Delhi: prentice- hall of India.

8. Kalani, A. (2008), "A Study of Effectiveness of Concept Attainment Model over Control Method for Teaching Science in Relation to Achievement and Retention", International Research Journal, 2 (5), 20-22.

9. Kumar, A. and Mathur, M. (2013), "Effect of Concept Attainment Model on Acquisition of Physics Concepts", Universal Journal of Educational Research, 1(3), 165-169.

10. Shamnad, N. (2005), "Effectiveness of Concept Attainment Model on Achievement in Arabic Grammar of Standard IX Students", Retrieved http://arabicuniversitycollege.yolasite.com/resources/Faculty/NS/Dissertations.

11. Sreelekha, S. and Nayar, A.K. (2004), "The Effectiveness of Concept Attainment Model in Learning Chemistry at Secondary level", New Delhi: NCERT publication.

12. Verma, C.P. (2001), "A Comparative Study of the Effectiveness of Mastery Learning Model and Inductive Thinking Model on Pupils' Achievement in Science and their Creative Thinking Abilities", Unpublished Doctorate Thesis, Rohtak: M.D.University.

13. Vyas, B.K. (2014), "Effect of Concept Attainment Model of Instruction on Achievement in Mathematics of Under Achiever and Over Achiever Students of Secondary Schools", Unpublished Doctorate Thesis, Rajkot: Saurashtra University.

14. Yaghini, M. (2008), "Evaluating the Effects of Concept Attainment Teaching Model and Traditional on the Learning Concepts of Numerical Mathematics during Preschool from the Perspective of Educators in Shiraz", Unpublished Master's thesis, Iran: Islamic Azad University, Arsanjan. 